\title{
sciforum
}

Conference Proceedings Paper

\section{Transient-mean flow interactions over the northern tropical Americas}

\author{
Víctor Magaña*, Eduardo Herrera \\ Published: 11/11/2017 \\ Academic Editor: Raquel Nieto \\ 1 Instituto de Geografía, UNAM, Mexico \\ * Correspondence: victormr@unam.mx; herreraztegui@gmail.com
}

\begin{abstract}
The Mid Summer Drought (MSD) over the Mesoamerican region constitutes a unique feature of its precipitation seasonal cycle. The MSD is a relative minimum in convective activity during July and August that coincides with an intensification of the Caribbean Low Level Jet (CLLJ) (mean flow at $925 \mathrm{hPa}$ ). There is not a unique theory on what maintains the CLLJ is, but the effect of the mean meridional convergence of easterly momentum related to tropical extratropical interactions over the Caribbean Sea, appars to play an important role. The barotropicaly unstable nature of the CLLJ shows that when this mean circulation is intense the amplification of high frequency transients (eg, easterly waves) is inhibited. Empirical observational evidence shows that as the CLLJ intensifies above a certain magnitude, transient activity decreases. Such transient activity is related to easterly waves, a key element in producing precipitation over the tropical Americas. Therefore, the CLLJ acts as a modulator of tropical convection in relation to the MSD, as the period of relatively minor tropical convection coincides with a decrease in high frequency Perturbation Kinetic Energy (PKE). Its role in the modulation of convective activity over the tropical Americas on interannual and even on interdecadal time scales makes it one of the key elements to understand climate variability over the tropical Americas.
\end{abstract}

Keywords: MSD; CLLJ; tropical Americas.

\section{Introduction}

The Mid Summer Drought (MSD) over the Mesoamerican region constitutes a unique features of its seasonal cycle in precipitation [1]. The MSD is a relative minimum in convective activity during July and August that coincides with an intensification of the Caribbean Low Level Jet (CLLJ) (mean flow at $925 \mathrm{hPa}$ ). Until now, it is not clear what the mechanism that maintains the CLLJ is, but it appears that the effect of the mean convergence of easterly momentum, by means of tropical extratropical interactions over the Caribbean Sea, plays an important role [2]. Cook and Vizy (2010) observed that an intense CLLJ is related to negative precipitation anomalies in summer over most of the IAS region [3]. Magaña et al. (2003) found that during El Niño years, the CLLJ is anomalously strong, producing upwelling off the Caribbean coast north of the South American coast. Cooler SSTs and enhanced vertical wind shear result in less tropical cyclone activity over the Caribbean Sea [4].

On intraseasonal time scales, the existence of the MSD is related to the dynamics of the CLLJ over the Caribbean. An intense CLLJ in July tends to reduce convective activity over most of the Mesoamerican region [2]. On interannual time scales, El Niño enhances the mean intensity of the CLLJ and a decrease in season summer precipitation is observed [4]. Even on interdecadal time scales, 
The 1st International Electronic Conference on Hydrological Cycle (CHyCle-2017), 11 -16 November 2017; Sciforum Electronic Conference Series, Vol. 1, 2017

an persistently intense CLLJ results in prolonged periods of drought over Mesoamérica [5]. Therefore, the mean intensity of the CLL is a key element to generate adequate condition to promote or inhibit the amplification of transient systems that produce precipitation over the region.

The range of intensity of an easterly barotropically intense flow to amplify perturbation has been examined in a number of studies, following the original ideas of Kuo [6]. In the present study, we present eviden on the modulation of transient activity by the intensity of the CLLJ. The transient activity is examined by means of the high frequency Perturbation Kinetic Energy (PKE) in the region of the Caribbean Sea.

\section{Experiments}

The data used in this study are the NCEP/NCAR daily reanalyses data with a spatial resolution of $2.5^{\circ} \times 2.5^{\circ}$ for the 1979-2009 period [7]. Zonal and meridional components of the wind and geopotential height at $1000 \mathrm{hPa}, 850 \mathrm{hPa}$ and $700 \mathrm{hPa}$ are used to characterize the mean circulations over the tropical Americas. From European Centre for Medium-Range Weather Forecasts (ECMWF) ERA-Interim [8], we used daily (four time day mean) and monthly data in the period of 1979 to 2013 (35 years) for 1000, 925, 850, 700, 500, 300, and $100 \mathrm{hPa}$ levels.

High frequency transients are obtained by means of a band pass filter with a maximum response around the frequency of ( 5 days)- 1 , and $50 \%$ response in the (3 days)- 1 and (10 days)- 1 frequency band, using a Butterworth filter as the one described in Murakami [9].

\section{Results}

Perturbation Kinetic Energy is defined as

$$
\mathrm{PKE}=1 / 2\left(\mathrm{u}^{\prime 2}+\mathrm{v}^{\prime 2}\right)
$$

and corresponds to a measure of high frequency transients. In the tropical regions, and particularly over the Intra Americas Seas (IAS), the transients in summer in the range between 3 and 10 days are mainly related to easterly waves and tropical cyclones. The summer monthly average of PKE shows that the CLLJ becomes stronger at the beginning of summer in the jet entrance region (from May through July). In August, as the CLLJ turns weake and there is less PKE in the eastern Caribbean. In September, there is a second maximum in PKE over the Atlantic and the eastern Caribbean, in relation with more African and easterly wave activity (Figure 1).

a)

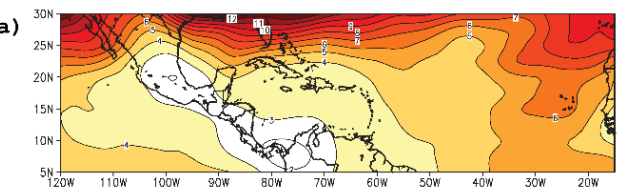

b)

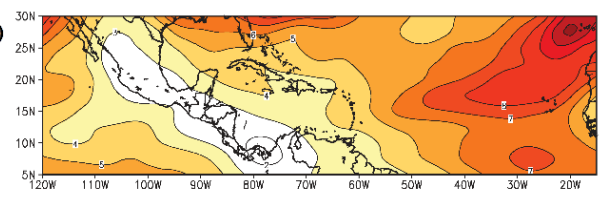

c)

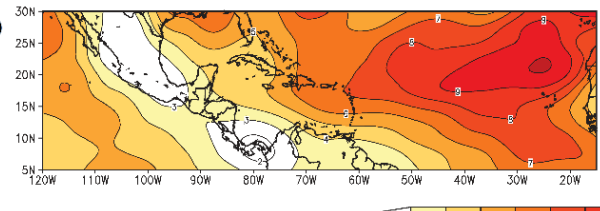

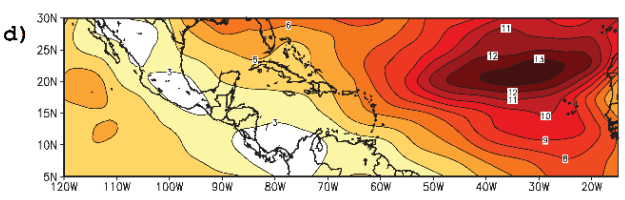
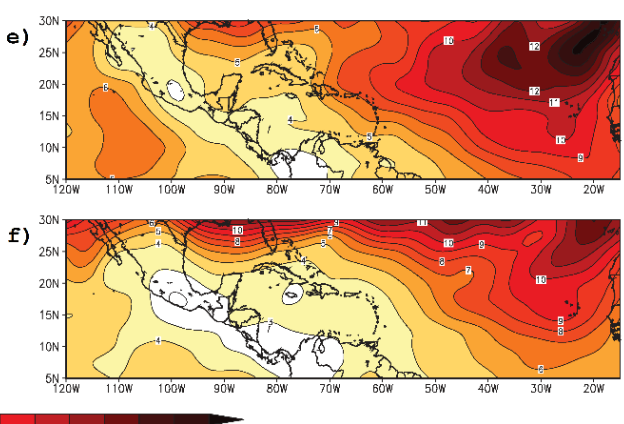

Figure 1. PKE $\left(\mathrm{m}^{2} \mathrm{~s}^{-2}\right)$ at $700 \mathrm{hPa}$ using high frequency (3-10 days) transients for a) May, b) June, c) July, d) August, e) September, and f) October. 
The 1st International Electronic Conference on Hydrological Cycle (CHyCle-2017), 11 -16 November 2017; Sciforum Electronic Conference Series, Vol. 1, 2017

To see more clearly PKE changes we can use monthly differences (Figure 2). As easterly waves activity begins PKE grows mainly for easterly Atlantic region and almost reach the Caribbean (Figure $2 \mathrm{a}$, and $2 \mathrm{~b}$ ), but from July to August there is a notorious descent (Figure 2c). Prevously it is mentioned the second maximum in September and in October PKE falls because generation of easterly waves decreases too (Figure 2d, and 2e respectively).

a)

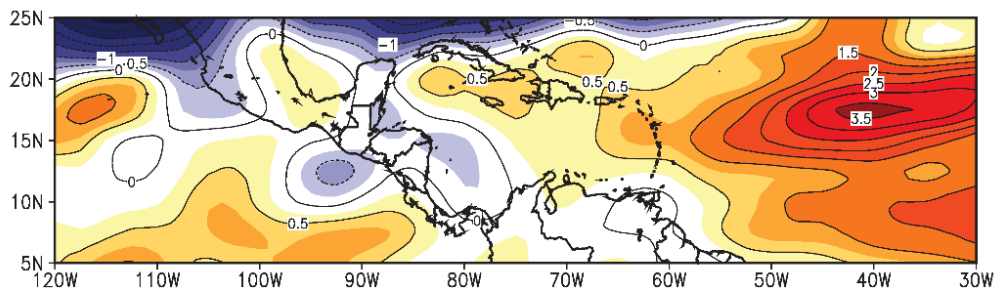

b)

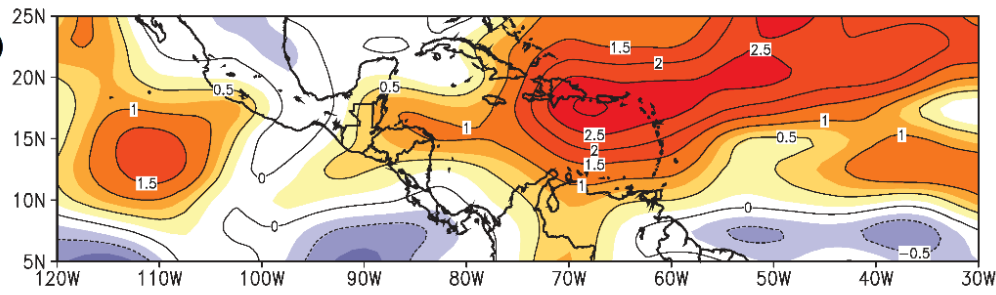

C)

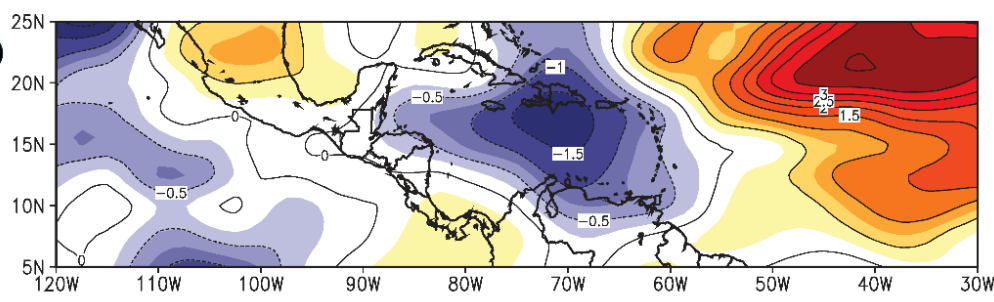

d)
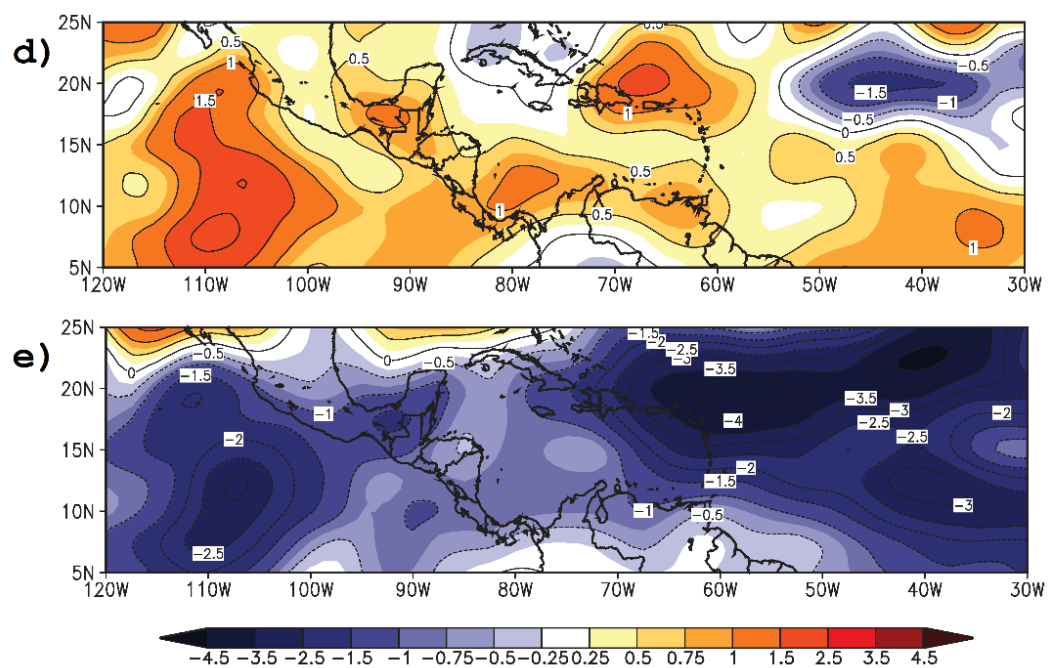

Figure 2. Climatological monthly difference of PKE $\left(\mathrm{m}^{2} \mathrm{~s}^{-2}\right)$ at $700 \mathrm{hPa}$ using high frequency (3-10 days) transients: a) June minus May, b) July minus June, c) August minus July, d) September minus August, and e) October minus September.

Predominant levels for transients activity as easterly waves are 700 and $850 \mathrm{hPa}$, then in July at Caribbean region some mechanism as a circulation drives CLLJ to reach a maximum, moving momentum to this zone. This kind of circulation is refered by Herrera et al. [2] and through PKE vertical cross section we can notice this behavior too (Figure 3). 


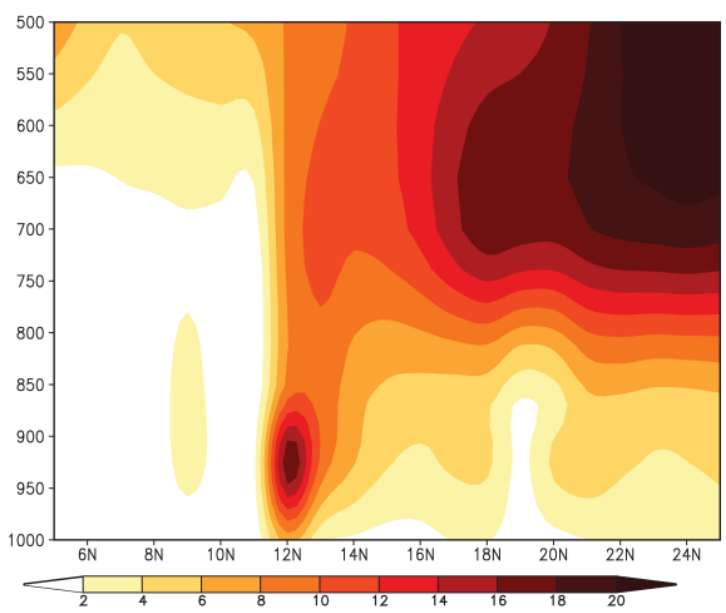

Figure 3. Vertical cross section of climatology of PKE $\left(\mathrm{m}^{2} \mathrm{~s}^{-2}\right)$ using high frequency (3-10 days) transients at $75^{\circ} \mathrm{W}$ fix for July.

Easterly waves observed over the Caribbean Sea may be the result of African waves propagating into the Caribbean Sea or local perturbations amplifying at the CLLJ entrance region. The PKE analyses show that the maximum input of PKE from the Atlantic occurs in July, when the CLLJ reaches maximum intensity. However, it is not clear why with more PKE over the Atlantic, less PKE is observed in August over the Caribbean Sea. This may be due to a mean flow condition that does not favor the amplification of the perturbations once they reach the Caribbean sea. A CLLJ of more than $15 \mathrm{~m} / \mathrm{s}$ may be too strong for easterly waves with a wavelength of around $2000 \mathrm{~km}$ to be amplified, or may induce an intense vertical wind shear that inhibits the formation of tropical cyclones in the region [10] The decrease in easterly wave activity from July to August is related to a decrease in precipitation and the MSD and shows as a decrease in PKE.

A composite analyses of summer precipitation over the northern tropical Americas shows that during periods of intense easterly wave activity, accumulated rainfall is larger than during periods of less easterly wave activity.

\section{Discussion}

The study of atmospheric barotropically unstable flows indicate that within a range of mean flow intensity, perturbations with certain spatial characteristics may amplify. In the case of the dynamics of summer climate over the Caribbean Sea, the CLLJ corresponds to a barotropically unstable quasi.stationary summer circulation that may favor the amplification of transients such as African waves that move over the Atlantic ocean. However, if the the CLLJ is stronger that a certain thrshold, the typical perturbations that approach the Caribbean sea may not amplify under barotropically unstable conditions. This appears to be the case during July and August, or during years of an anomalously strong CLLJ, given that high frequency PKE, used as a measure of transient activity tends to decrease under such conditions.

\section{Conclusions}

The determination of what sources of zonal momentum are responsible for the amplification of the CLLJ is a relevant problem if more adequate seasonal predictions of precipitation are intended. The present analysis shows empirical evidence that under periods of intensification of the CLLJ transient activity in the Caribbean Sea, and precipitation over a large region of the tropical northern Americas tend to decrease. 
The 1st International Electronic Conference on Hydrological Cycle (CHyCle-2017), 11 -16 November 2017;

Sciforum Electronic Conference Series, Vol. 1, 2017

Conflicts of Interest: The authors declare no conflict of interest.

\section{Abbreviations}

The following abbreviations are used in this manuscript:

MSD: Mid Summer Drought

CLLJ: Caribbean Low Level Jet

\section{References}

1. Magaña V, Amador J, Medina S. The midsummer drought over Mexico and Central America. J. Climate 1999, vol. 12, pp. 1577-1588. https://doi.org/10.1175/15200442(1999)012\%3C1577:TMDOMA\%3E2.0.CO;2

2. Herrera, E., Magaña, V., and Caetano, E. Air-sea interactions and dynamical processes associated with the midsummer drought. Int. J. Climatol. 2015, 35: 1569-1578. doi: 10.1002/joc.4077

3. Cook, K.H., and Vizy E.K. Hydrodynamics of the Caribbean low level jet and its relationship to precipitation. J. Climate 2010, vol. 23, pp. 1477-1494. https://doi.org/10.1175/2009JCLI3210.1

4. Magaña, V.O., Vázquez, J.L., Pérez, J.L., and Pérez, J.B. Impact of El Niño on precipitation in Mexico. Geofísica Internacional 2003, vol. 42-3, 313-330.

5. Méndez, M., and Magaña, V. Regional Aspects of Prolonged Meteorological Droughts over Mexico and Central America. J. Climate 2010, vol.23, 1175-1188. DOI: 10.1175/2009JCLI3080.1

6. Kuo, H. L. Dynamic instability of two-dimensional non-divergent flow in a barotropic atmosphere. J. Meteor. 1949, 6, 105-122.

7. Kalnay E, Kanamitsu M, Kistler R, Collins W, Deaven D, Gandin L, Iredell M, Saha S, White G, Woollen J, Zhu Y, Chelliah M, Ebisuzaki W, Higgins W, Janowiak J, Mo KC, Ropelewski C, Wang J, Leetmaa A, Reynolds R, Jenne R, Joseph D. The NCEP/NCAR 40-Year Reanalysis Project. Bull. Amer. Meteor. Soc. 1996, vol. 7, 437-471.

8. Dee DP, Uppala SM, Simmons AJ, Berrisford P, Poli P, Kobayashi S, Andrae U, Balmaseda MA, Balsamo G, Bauer P, Bechtold P, Beljaars ACM, van de Berg L, Bidlot J, Bormann N, Delsol C, Dragani R, Fuentes M, Geer AJ, Haimberger L, Healy SB, Hersbach H, Hólm EV, Isaksen L, Kållberg P, Köhler M, Matricardi M, McNally AP, Monge-Sanz BM, Morcrette J-J, Park B-K, Peubey C, de Rosnay P, Tavolato C, Thépaut JN, Vitart F. The ERA-Interim reanalysis: configuration and performance of the data assimilation system. $Q$ J R Meteorol Soc, 2011, 137:553-597. doi:10.1002/qj.828

9. Murakami, M. Large-Scale Aspects of Deep Convective Activity over the GATE Area. Mon. Wea. Rev. 1979, vol. 107, 994-1013.

10. Inoue, M,. Handoh, I.C. and Bigg, G.R. Bimodal distribution of tropical cyclogenesis in the Caribbean: Characteristics and environmental factors. J. Climate, 2002, 15, 2897-2905. 
The 1st International Electronic Conference on Hydrological Cycle (CHyCle-2017), 11 -16 November 2017; Sciforum Electronic Conference Series, Vol. 1, 2017

(C) 2017 by the authors; licensee MDPI, Basel, Switzerland. This article is an open access article distributed (C) under the terms and conditions of the Creative Commons by Attribution (CC-BY) license (C) 